\title{
The Role of the Maritime Industry and Vocational and Technical Education and Training in the Economic Development of Nigeria
}

\author{
Prof. Victor F. Peretomode \\ Professor Victor F. Peretomode is a Professor of Educational Administration \& Higher Education, Faculty of \\ Education, Delta State University, Abraka. Nigeria
}

\begin{abstract}
This paper is based on the premise that the high unemployment of youth in Nigeria can be minimized and the crises arising therefrom can be greatly reduced and the economy strengthened if Nigeria develops a robust and virile maritime industry and quality vocational and technical education and training programme. The paper explains the terms maritime industry and vocational and technical education and highlighted the possible contribution of robust maritime activities to the nation's economy. It also addressed the importance of Vocational and technical education and training and its role in national development.
\end{abstract}

Keywords: Economic development, Nigerian Maritime Administration and Safety Agency (NIMASA), Maritime Industry, National development, Technical Training, Vocational Education.

\section{Introduction}

It has been estimated that Nigeria has a population of 170 million people out of which forty-five percent are below poverty line and 5.4 million Nigerian Youth are unemployed. The unemployed include both graduates of Senior Secondary and tertiary institutions and do not have any employable skills needed at both the small and medium scale enterprises and other major sectors of the economy such as the maritime industry. It is posited that the economic impact of the maritime industry and the role of technical and vocational education and training (TVET) in the provision of the needed skills to the youth and manpower development in the economic development of a country such as Nigeria cannot be overemphasized. This paper therefore, explained the terms maritime industry, vocational and technical education and training and highlighted possible beneficial impact of marine activities to the Nigerian economy and the importance of TVET and its role in national economic development.

\section{Maritime Industry}

The maritime industry is a sub-sector of the transport sector. It includes people working for transportation (ship, rail, truck and towboat/barge) companies, freight forwarders and custom brokers; stevedoving companies; labor unions; chandlers; warehouses; ship building and repairs importers/exporters and pilot associations. In its broadest sense, maritime industry involves all enterprises engaged in the business of designing, constructing, manufacturing, acquiring, operating, supplying, repairing and/or maintaining vessels, managing and/or operating shipping lines, stevedoving and customs, brokerage services, shipyards, dry docks, marine railways, marine repair shop, shipping and freight forwarding services and similar enterprises. (wiki.answers.com,2014).

It has been pointed out that globally, the maritime industry sub-sector accounts for nearly $90 \%$ of transport requirements of the world. It has been stated that seaborne trade, which also constitutes a larger chunk of water transport trade accounts for over 60\% of the total Gross Domestic Product (GDP) of the sixteen (16) countries that make up the Economic Community for West African States (ECOWAS) (Airahilobhor,2008).

In Nigeria, there is the Nigerian Maritime Administration and Safety Agency (NIMASA) [formerly the National Maritime Authority (NMA)] founded on 1st August, 2006, when NMA was merged with the Joint Maritime Labour Industrial Council - both formerly parastatals of the Federal Ministry of Transport (Mwalinu,2005). The agency was established for the purpose of regulating the Maritime Industry in Nigeria. NIMASA provides maritime services, with focus on;

1. Effective Maritime Safety Administration

2. Maritime Labour Administration

3. Maritime Labour Regulation

4. Maritime Pollution Prevention and Control

5. Search and Rescue

6. Cabotage Enforcement

7. Shipping Development and Ship Registration 
8. Training and Certification of Seafarers, and

9. Maritime Capacity Development

In Oron, Akwa Ibom State, is a Maritime academy called The Maritime Academy of Nigeria. Originally, it was called Nautical College of Nigeria and established in 1979. It was designed for the education and training of shipboard officers, ratings and shore-based management personnel. The academy's mandate was in 1988 expanded to include training all levels and categories of personnel for all faces of the maritime industry. By the end of 2008, the Nigerian Maritime Academy had trained about 4,300 Nigerian Merchant Navy Officers and more than 65,000 other workers in Marine Operations (Wikipedia, 2014). Most of the personnel required to engage in this vast maritime, sub-sector are expected to be skilled or semi-skilled in the various facets of the industry. But in Nigeria, training in the use of the hand-skills, trades or vocations is looked down upon. As a result only few take to training in the vocations.

According to Wikipedia (2014), NIMASA stated that 50,000 seafarers are needed for the Nigerian Shipping Industry to realize its full potential. As of 2009, Nigeria had less than 3,000 seafarers and that about 2,000 vessels were engaged in cabotage, on local trade between Nigerian ports, with mostly foreign crews (NIMASA,2013). This implies an area of need for skilled manpower in the Nigerian economy. From the statistics provided by NIMASA, it will take quite some time to be able to fill this gap because the Nigerian Maritime academy expected to help produce this needed manpower can only admit less than $33 \%$ of the 3000 candidates that apply to it each year due to shortage of classrooms and accommodation, lack of training facilities and unavailability of seafaring vessels on which students could complete their mandatory one year sea term. Students seeking proper training therefore, had to attend the Regional Maritime University in Accra, Ghana (Wikipedia,2014). Presently, the Federal Government of Nigeria, through NIMASA, is establishing a Maritime University in Okerenkoko in Delta State and another Maritime College at Okoloba in Delta State. When will these institutions be completed, furnished and equipped and staffed so as to become operational is unknown.

\section{Vocational and Technical Education}

Education is a critical investment in the future of a nation. It is the key agent for the Socio-economic, political, scientific and technological development of a nation. But what type of education can bring about a country's growth and development? It has been posited that it is a type of education that can improve the quality of employees and this requires that they be trained in modern professionally based and job oriented technical, technological and vocational education programmes (Alam,2008). Dike (2009) specifically argued that TVET has been an integral part of national development strategies in many societies because of its impact on productivity and economic development. He asserted that Vo-tech education holds the key to national development.

Technical education is a planned programme of courses and learning experiences that emphasize the understanding and practical application of basic principles of science and modern technology, rather than the attainment of proficiency in manual skills that is properly the concern of vocational education. Technical education has its objectives the preparation of graduates for occupations that are classed above the skilled crafts but below the scientific or engineering professionals. People so employed are frequently called technicians. (Encyclopedia Britainnica,2014).

Vocational education, also known as Vocational Education and Training (VET), is an aspect of education that prepares people for specific trades, crafts and careers at various levels. The training is usually based on manual or practical activities, traditionally non-academic, related to a specific trade, occupation or vocation. (en.wikipedia.org/wiki/vocationaleducation,2014). Vocational education teaches skills which are directly related to a specific job or profession, as opposed to academic education which looks at a subject in a more abstract manner. Vocational education is offered at the secondary school level, while technical education is offered at the post -secondary level institutions, usually at below first degree level.

Vocational and technical education gives individuals the skills to "live, learn and work as productive citizens in a global society. As the National Policy on Education (NPE 2004) explained, technical and vocational education is used as a comprehensive term referring to those aspects of the educational process involving, in addition to general education, the study of technologies and related sciences and the acquisition of practical skills, attitudes, understanding and knowledge relating to occupations in various sectors of economic and social life. Vo-tech-education can therefore be considered as a method of alleviating poverty (NPE 2004:24) as it provides "opportunity also for people in urban and rural communities to equip themselves with skills that lead to productive and satisfying lives and fit, into the needs of the Nigerian labour market (Akinseinde, 2014: 2-3)

In Nigeria, most youth shun the acquisition of skills and any training that has to do with the use of the hand because that takes time, in their view, to become a wealthy man. The country has come to be characterized by this get-quick-rich syndrome that they prefer to be idle, and remain dependent on others in spite of being 
aware of the popular adage that "the idle mind is the devil's workshop". They fail to see the value in skills' acquisition.

The goals of technical and vocational education as stipulated in the NPE (2004) are to;

a. provide trained manpower in the applied sciences, technology and business particularly at craft, advanced craft and technical levels;

b. provide the technical knowledge and vocational skills necessary for agricultural, commercial and economic development;

c. give training and impart the necessary skills to individual who shall be self-reliant economically.

Vocational and technical trades are numerous. They can be grouped under the following; Mechanical trades, Welding and Fabrication, Computer craft practice, Electrical Engineering trades, Building trades, Wood trades, Hospitality trades, Textiles trades, Printing trades, Beauty Culture trades, Business trades, Leather goods manufacture (NPE-2004:27-28).

\section{Contributions Of The Maritime Industry To The Nation's Economy}

The significant impact of the maritime industry to a nation's economy is extensive, particularly those with coastal and inland waterways like Nigeria. The maritime industry is a key sector in the Nigerian economy. Nigeria has a coastline of over $8000 \mathrm{~km}$. Shipping therefore, is a very critical sub-sector in this sector. Chief Ojo Madueke, former Minister of Transport in Nigeria, in 2001 recognized the strategic importance of marine transport to the Nigerian economy when he was quoted to have said that the maritime industry "is to the Nigerian economy what the artery is to the blood circulation system of the body". The current Minister of Transport, Senator Idris Umar, has said that the maritime sector of the economy remains key to meeting the yearning and aspirations of Nigerians, especially the youth.

The maritime industry which is a subsector of the transport sector, globally accounts for over $70 \%$ of transport requirement of the world: maritime activities are expanding, bringing benefits to people across the world. The sector is a major catalyst for socio-economic development and international competitiveness in a fast changing, globalized world (FinItell, 2014). It also affects a wide range of aspects of modern societies and their development.

According to Haralambides(2014), in the United States, for example, it has been recently calculated that for every job in the merchant marine, 4.4 additional jobs were created in the economy, and for every dollar of household income in this sector, 3.4 dollars of additional income is created in the economy by and large. Similar results have also been demonstrated in Holand, UK, Italy, and Belguin. And in the European Union (EU) maritime regions account for about $40 \%$ of its Gross Domestic Product (GDP).

Nigeria is endowed with a vast coastline as well as navigable inland waterways and about $80 \%$ shipping business that takes place in the whole of West Africa is done in Nigeria alone. When it is recognized that Nigeria is the 6th largest producer of crude oil in the world and has a large volume of gas reserves, rich in natural resources and agricultural produce, a major importer of finished and semi-finished goods, and its crude oil and gas are exported to international markets by sea where they are sold to earn foreign currency to ensure the country's development, then the economic significance of the maritime industry becomes more self-evident. This is further enhanced by the fact that statistics have shown that over $80 \%$ of the global oil is transported by ship, in the case of Nigeria it is $\mathbf{1 0 0 \%}$. The Nigerian oil and gas sector requires huge shipping and logistic services for its smooth operations. This subsector of the maritime industry is estimated at over \$3billion (Haralambides,2014). The maritime sector's contribution to the GDP of six developing economies in 2012 was as follows:-

$\begin{array}{lll}\text { India } & = & 28.1 \\ \text { China } & = & 9.7 \\ \text { Russia } & = & 5.9 \\ \text { Brazil } & = & 2.8 \\ \text { South Africa } & = & 1.3 \\ \text { Nigeria } & = & 0.15\end{array}$

Hercules E. Haralambides of the Center for Maritime Economics and Logistics, Erasmus University, Rotterdam, reported that statistics from the Nigerian Ports Authority (NPA) on ship call to Nigeria revealed that between 2009 and 2012, Nigeria's tonnage grew from 82million tons to over 150million with an estimated payment rising from $\$ 4.1$ billion to above $\$ 7.5$ billion annually, but participation of Nigerian was zero. The statistics also show that Nigeria exported about 900 million barrels of crude oil annually, but foreign vessels earn the freight of about $\$ 2.25$ billion a year carrying the country's crude with no freight earning benefit to Nigeria. Nigeria has no national shipping line. 
It should be noted at this point that shipping as a mode of transport, provides the cheapest and most efficient means of moving large volumes of import and export round the world thereby creating jobs and adding value to the economy (Ma,2010:13).

In addition to the above, the importance of the maritime industry (including maritime transport) can be summarized as follows:

- It brings about diversification of investment opportunities. Elem (2008:24), for example provides a broad list of investment corridors to be;

$>$ Dry docking

$>$ Ship repairs - repair and maintenance of vessels

$>$ Coastal shipping services - providing and operating cargo handling a quay facilities.

$>$ Trawlers

$>$ Terminal/jetty infrastructure

$>$ Offshore construction and fabrication

$>$ Supply boats to offshore oil fields

$>$ Crew boats

$>$ Tug boats/Anchor handling

$>$ Diving support vessels

$>$ Cables/pipe laying vessels

$>$ Barges/House boats

$>$ Dredgers

$>$ Passengers/fery services

$>$ Tourism services (Elem, 2008:24)

$>$ Pilotage and towage services

$>$ Supply of water and fuel to vessel at anchorage or mooring buoys

$>$ Industrial areas/warehousing/offices

$>$ Development of ports

The numerous unemployed youth can be sensitized and trained in the necessary skills to fill the vacancies in these areas of needs. By so doing, the unemployment situation already at a crisis situation can be greatly reduced. This will also have a ripple effect on poverty reduction and increased per capital income in Nigeria.

Other contributions of the maritime industry to Nigeria economy have been well articulated and they include the following:

1. Diversification of the economy as it provides numerous opportunities for investment (Lazarus, 2013)

2. Serves to stimulate import and export trade by way of providing surface transport through which goods are moved by sea on a massive scale (Balarabe, 2004)

3. Maritime (Shipping) trade has played a major role in Nigerian economic development, accounting for instance, for about $95 \%$ of the vehicular means of Nigeria international trade.

4. It has continued to provide employment and greater potential for the employment of more Nigerians as crew staff, mariners and dock workers in addition to various practitioners among which are freight forwarders (Okoloba, 2006).

5. Maritime transport also generates the much needed foreign exchange to the Nigerian economy. This is in the form of ship repairs, taxes and port fees and charges, among others. The policy of NIMASA to collect levy on gross freight from any vessel that calls at the Nigerian ports for export or import purposes, is another source of generating revenue (NIMASA, 2013).

6. Maritime transport has also provided opportunity for inland waterway transport, coastal and high sea trading and also made it possible for Nigerians to develop the skill and art for fish and shrimps trawling enterprise.

7. It can also promote tourism in the country and this can have positive impact on the employment of the unemployed (Igbokwe, 2001; Lazarus, 2013).

8. The ports in Nigeria, if fully developed, and the Nigeria Education system is able to provide the needed semi and skilled manpower, has the capacity to create millions of job opportunities. The Warri port, for example, a very small sea port, compared to those of Calabar, Port Harcourt, Tin-Can Island in Lagos, is said to have eighteen companies engaged in different activities (Sweet Crude, 2014).

\section{Vocational And Technical Education And Economic Growth}

Technical and vocational education and training is known to make important contributions to the economic growth of a country. Mupimpila and Narayana (2009) in their study in Botswana found a positive and significant relationship between economic growth and vocational and technical training in the country. Lewin 
(1993:14) stated that TVET seems to allow us to "kill several birds with the same stone". International Labour Organization (ILO) (2001) claims rightly so, that TVET is intended as a bold and courageous step to undertake in an age of changing scenario for economic life, technological advancement and globalization.

Howell (2002) points out that the economic competitiveness of a country depends on the skills of its workforce. The skills and competences of the work force in turn are dependent upon the quality of the country's education and training systems. And Vo-tech education is perceived as one of the crucial type of institution that should prepare and supply future workers with appropriate knowledge and skills to enhance their productivity and therefore promote economic growth (Finch,1993; Labaree, 1997,Min.1995).

Technical and vocational education has also become a tool for addressing the economic, social and political crises that are threatening the political and economic stability of some countries. This is due to rising unemployment, lack of semi-skilled and skilled workers, high dropout rates, and the changing demographic nature of the work force. These have placed the issue of Vo-tech education high on the educational reform agenda (Giroux, 1991) of most developing nations. For example, the Federal Government of Nigeria under President Goodluck Ebele Jonathan, haven foreseen the dangers inherent in the problem of out-of-school boys syndrome, has set up a National Implementation and Monitoring Committee for the integration of out-of-schoolboys from the South East and South-South States into the Basic Education Programme.

The Committee, among others, has been charged with the responsibility of planning and coordinating activities that will lead to the establishment of UBE Special Vocational Schools in each of the relevant states. The committee is also to develop special curriculum that will combine both basic and vocational skills/trades. The goal is to produce these boys with life skills and on graduation, to become useful to themselves, their family and community and also useful contributors to the sustainable economic development of their states and the nation. On completion, they will be self-employed and employer of labour.

The role of vocational and technical education and training in the economic and technological development of a country such as Nigeria includes:

1. Empowering the citizens with vocational and technical skills in any pursuit to enhance their productivity, and bringing them both immediate and lasting economic returns and national economic development (Dike, 2009).

2. Vocational and technical education programmes, if current, are more suitable than regular academic school programmes in responding to the rapidly changing nature of skills and technology.

3. Graduates of vo-tech schools have better employment opportunities than graduates from academic secondary schools. In addition, they are better and well prepared to enter the competitive workforce (Howell, 2002).

4. Graduates of Vocational and technical schools possess necessary critical thinking and problem solving skills and entrepreneurial skills necessary for survival and economic development in this era of knowledge economy and technological advancement and globalization.

5. There is high level of unemployment among graduates of academic programmes. Youth unemployment is about $80 \%$ and $10 \%$ are underemployed. On the other hand, employments among products of vocational and technical colleges are usually high while unemployment among them is low. Therefore the problem of juvenile delinquency and crime due to the absence of opportunity for works and lack of the necessary occupational skills to be self-employed and effectively function in today's world of work, can be greatly reduced if youths are given necessary vocational training that will keep them to be busy by becoming selfemployed (Dike,2007, Osalor, 2013).

6. The skills acquired through Vo-tech education and training enables youths to contribute to the growth and development of the nation and have increased personal freedom. The service sector has been noted for absorbing the biggest number of graduates of technical and vocational education and training in most nations.

\section{Conclusion}

A robust and virile maritime industry and quality Vo-tech education will no doubt have positive impact on the economic development of Nigeria. TVET can bring about reduction in unemployment, also has a positive role to play in improving the productivity of all workers and enhance the skills of those in the maritime industry and equip the unemployed with employable skills. If Nigeria is to become one of the twenty largest economies in the world by the year 2020, its leaders must properly equip laboratories and practical workshops in her technical and vocational institutions with the state-of-the art equipment and facilities, staff them with well trained professional Vo-tech teachers and develop relevant and up-to-date TVET courses. Nigeria must invest adequately in Vo-tech education and training because TVET has become the engine for sustainable economic development of nations. 
The maritime industry is of huge importance in Nigeria and its total value to the economic development of the country is difficult to quantify. One thing is clear though and that is the Nigerian maritime industry has not achieved optimum performance and its full potential as a tool for sustainable socio-economic development in the country has not been realized. This is due to lack of adequate infrastructure, lack of manpower and funding and the dominance of this sub-sector by foreigners. With the maritime industry been estimated to be bigger in size than oil and gas (Chukwu, 2013), leaders of this nation should invest substantially in the subsector so as to build a sustainable maritime industry capable of generating employment and revenue and foreign exchange that can surpass that of oil and gas exportation. This if done, would help to accelerate the socioeconomic development of Nigeria.

\section{References}

[1]. AfDevinfo (2014). National Maritime Authority. Hp://www.Afdevinfo.national-maritime-authority. Retrieved on 02-04-2014

[2]. Akinseinde, Samuel I. (2014). Technical Vocational Education and Training as catalyst for Human Capital Development and Poverty Reduction in Nigeria”. $33^{\text {rd }}$ in the series of Inaugural Lectures of Delta State University, Abraka, Nigeria, Thursday $20^{\text {th }}$ March, 2014. Abraka: University printing press.

[3]. Airahuobhor, Andrew (2011). "Controversy Trails FG Plan to Establish New Maritime Training Institutions". The Daily Independent (Lagos). Retrieved 20-03-2014

[4]. Chukwu Ignatius (2013). "Building a Sustainable Maritime Industry in Nigeria". Business Day, November 8

[5]. Ekpo, Imoh E. (2012). Impact of Shipping on Nigerian Economy: Implications for Sustainable Development. Journal of Education and Social Research, 2(7) October.

[6]. Elem, R. (2008). Economic opportunities available in the Nigerian Maritime Sector. The Voyage Magazine by NIMASA, April, p.12

[7]. Ezem, Francis (2013). "Maritime Industry Will Be Nigeria's Economic Mainstay Soon - NIMASA" National Mirrow, September 6.

[8]. Haralambides, H.E. (2014). "The Economic Impact of Shipping on the National Economy: www.myfinancealintelligence.com/html. Retrieved 04-02-2014

[9]. Igbokwe, Michael (2001). "The Importance of Maritime Transport in Nigeria Economy". Business Day, July.

[10]. Khalifa, M. and Abdul-Azia, A. (2010). Policies to Improve Capacity of Technical and Vocational Training to Meet SME's Needs. Jerusalem: Palestine. Economic Research Institute.

[11]. Lazarus, Okoroji (2013). "The Importance of Shipping Trade on Economic Growth in Nigeria". Lazokoroji.wordpress.com/January 4th, 2013

[12]. Ma,S. (2011). Lecture Notes, Handouts and Slides on Logistics, Malma World Maritime University.

[13]. Mwalinu, Charles (2005). “The Nigerian Legal System.” Peter Lang. ISBN 0-8204 7126-7

[14]. Osalor, Peter (2013). "Vocation and Technical Education - a Key to Improving Nigeria's Development". Vanguard, Tuesday, January $14^{\text {th }}, 2014$

[15]. Sweetcrude, February 2014, p.27

[16]. Wikipedia (2014). The Nigerian Maritime Administration and Safety Agency (NIMASA). Wikipedia - the free Internet Encyclopedia www.wikipedia.org.

[17]. $\quad$ www.proshareng.com (2014). Maritime Sector Needs over \$500m Bailout Fund to Revive Shipping. Retrieved 04-02-2014 